\title{
Joana d'Arc e seu entusiasmo: ecos do iluminismo inglês na construção da heroína nacional francesa
}

\author{
Joan of Arc and her enthusiasm: echoes of English enlightenment in the \\ construction of the French national heroine
}

Flávia Amaral ${ }^{\star}$

Universidade Federal dos Vales do Jequitinhonha e Mucuri (UFVJM), Diamantina, MG, Brasil

\begin{abstract}
RESUMO: Segundo Joana d'Arc, desde que ela tinha treze anos de idade, anjos e santos lhe visitavam revelando uma missão designada por Deus: coroar o Delfim como rei da França e libertar seu reino dos ingleses. Ao procurar uma explicação racional para tal fenômeno, muitos de seus biógrafos, do século XIX, vão recorrer à ideia de que Joana era imbuída de uma espécie de ímpeto, razão pela qual acreditava fortemente na veracidade de suas visões e na validade de sua missão. A discussão em torno da ideia de entusiasmo foi particularmente importante para moldar a imagem de heroína laica, atribuída à Donzela no século XIX. Tal debate, entretanto, está inserido em uma tradição que remonta ao século anterior, estando no âmago das discussões iluministas na Grã-Bretanha, especialmente nos escritos de David Hume. No presente artigo, iremos apresentar esse debate, evidenciando os principais argumentos mostrados por autores que desejaram encontrar uma racionalidade na trajetória da heroína. Além disso, pretendemos posicionar a veemente crítica de Voltaire à Donzela e discutir sua recepção pela historiografia oitocentista que, ao que parece, encontrou na ideia de entusiasmo o eixo argumentativo para uma resposta a Voltaire, como fica evidente, por exemplo, na obra de Michelet.
\end{abstract}

PALAVRAS-CHAVE: Joana d’Arc. Historiografia. Iluminismo.

\begin{abstract}
According to Joan of Arc, since she was thirteen years old, angels and saints visited her revealing a mission designed by God: crowning the Delfin as king of France and liberating his kingdom from the English. Looking for a rational explanation for this phenomenon, many of her $19^{\text {th }}$ century biographers will resort to the idea that Joana was imbued with a kind of impetus, which is why she strongly believed in the veracity of her visions and the validity of her mission. The discussion around the idea of enthusiasm was particularly important in shaping the image of the lay heroine, attributed to the Maiden in the $19^{\text {th }}$ century. Such a debate, however, is part of a tradition that dates back to the previous century, being at the heart of Enlightenment discussions in Britain, especially in the writings of David Hume. In this article, we will present this debate, highlighting the main arguments presented by authors who wished to find a rationality in the heroine's trajectory. Furthermore, we intend to position Voltaire's vehement criticism of the Maiden and discuss his reception for $19^{\text {th }}$ century historiography which, it seems, found in the idea of enthusiasm the argumentative axis for a response to Voltaire, as is evident, for example, in Michelet's work.
\end{abstract}

KEYWORDS: Joana d'Arc. Historiography. Enlightenment.

\footnotetext{
* Professora da Universidade Federal dos Vales do Jequitinhonha e Mucuri (UFVJM), Diamantina, MG, Brasil. Pós-doutoranda no Programa de Pós- Graduação em História da Universidade Federal de Minas Gerais (UFMG). Doutora em Historia Social pela Universidade de São Paulo (2012). E-mail: flaviaaamaral@hotmail.com. https://orcid.org/0000-0002-5371-8919.
} 


\section{O tema do entusiasmo na historiografia joânica oitocentista}

A palavra entusiasmo tem origem grega: $e n+$ theos, literalmente, 'em Deus' ou "possuído por Deus”. As várias referências ao entusiasmo mostram que, de fato, foi um tema discutido por muitos (OLIVEIRA, 2006). Ainda que o sentido primeiro do termo seja o de inspiração divina, ele foi sofrendo alterações semânticas ao longo do tempo. Estando presente em Platão e posteriormente em Plotino, chega a Giordano Bruno para quem o entusiasmo significava o eroico furore que nada tinha a ver com influências divinas. Bruno entendia que o entusiasmo poderia levar o homem a desvendar os mistérios do universo. Mais adiante, no século XIX, esse tema foi associado ao debate sobre a inspiração divina de Joana d'Arc, em muitas obras, como veremos a seguir.

Analisando o processo que levou à condenação de Joana d'Arc, Clément de L'Averdy considerou que a firmeza de suas respostas diante dos questionamentos dos inquisidores indicava que a Donzela ${ }^{1}$ era movida por uma espécie de obstinação. Suas palavras pareciam estar animadas por "exaltações de espírito das quais é capaz uma imaginação tão suscetível como parece ter sido a sua." ${ }^{2}$ (L'AVERDY, 1790. p. 57). De fato, também muitos autores do século XIX preocuparam-se em explicar de uma forma racional não só a solidez e clareza com que Joana respondeu a seus juízes, mas também seu espírito de liderança.

Berriat Saint-Prix, em 1817, procurou mostrar que as açôes de Joana não tiveram causas transcendentais, mas, sim, naturais. $\mathrm{O}$ autor diagnostica na heroína algo que, segundo ele, faltava ao rei e à sua corte - uma espécie de coragem extasiante no coração. Por esse motivo, os franceses realmente acreditavam em sua inspiração e missão divinas. Sendo possível dar uma explicação natural para os eventos, não se deveria buscar uma interpretação miraculosa. Sua análise vai na direção de contextualizá-los:

Não se deve levar em conta a época em que viveu? É justo transportar o século XVIII para o começo do XV e transformar em filósofos uma pobre camponesa e soldados grosseiros? [...] Naquele período a superstição era uma doença universal, nutrida pela ignorância. Nascida em meio às guerras civis e estrangeiras travadas em meio ao ódio pelos ingleses, testemunha das devastaçôes contínuas de seu país, em meio a males que pareciam não ter fim, é tão extraordinário que sua imaginação exaltada e ardente converteu muitas vezes durante o sono suas esperanças em realidade, e que por fim, dotada de muita coragem ela quisesse executar o que acreditava de boa fé ser uma inspiração da Providência? [...] Quanto à eloquência, seus discursos rústicos sem correção e ornamento, só oferecem aquilo que há na natureza fortificado pela persuasão e pelo entusiasmo. (SAINT-PRIX, 1817, p. 60-61)

O entusiasmo seria um estado de espírito capaz de garantir a crença absoluta de Joana em sua missão, levando-a, inclusive, a dar respostas desconcertantes diante dos teólogos do Tribunal da Santa Inquisição. Da mesma forma que sua atitude entusiasta no palácio de Chinon a levou a reconhecer o Delfim disfarçado em meio a outros nobres, ela lhe garantia eloquência nas respostas ao longo do processo. Algumas alcançaram o patamar de sentenças ou máximas. Quando, por exemplo, lhe perguntaram se ela considerava estar na Graça de Deus, Joana replica: "Se eu não estiver que Ele me coloque, se eu estiver que Ele me mantenha” (QUICHERAT, 1841, v. 1, p. 65). Para Saint-Prix, essas respostas também tinham origem no seu entusiasmo: "[...] em cada resposta a mesma simplicidade, a mesma segurança, e às vezes essa eloquência que, se deve repetir, resulta do entusiasmo.” (SAINT-PRIX, 1817, p. 312). 
Esse entusiasmo não era retido por ela, mas transmitido a todos: "Através de seu aspecto, de seus discursos o entusiasmo ia do exército à guarnição e aos habitantes; a cidade se torna então invencível.”. Nas batalhas “[...] os soldados ficavam eletrizados pela audácia de Joana [...]” (SAINTPRIX, 1817, p. 64-65). Assim define-se seu heroísmo, fundamental na vitória francesa de 1429, em Orléans.

O triunfo de Carlos VII teria ocorrido "[...] graças ao desenvolvimento de seus guerreiros e de seu povo, a eventos fortuitos e jamais a seus trabalhos ou esforços." (SAINT-PRIX, 1817, p. 36). Saint-Prix afirma que, em várias expedições, Carlos VII não demonstrou liderança, não se esforçou para encontrar seus os aliados e, dessa forma, antigos defensores de sua coroa deixaram de apoiá-lo. Sobre a atitude de Carlos por ocasião do Cerco de Orléans, ele critica:

[...] a conduta de Carlos é que fornece ampla matéria se não se sentir uma espécie de aborrecimento e quase desgosto ao apresentar um príncipe que conserva tanta apatia entre indivíduos que se distinguem por tantas realizações. Tudo o que se obteve dele foi que viesse a Loches, que se aproximasse alguns quilômetros de Orléans. Indigna-se diante de tal inércia logo que se examina a atividade de Joana d'Arc. (SAINT-PRIX, 1817, p. 73).

A inércia de Carlos é obviamente apresentada em contraposição à ação entusiasta de Joana. Em relação à atitude de Carlos VII, na ocasião da prisão de Joana, em Compiègne, e de seu cativeiro, em Rouen, Saint-Prix critica duramente o rei:

Durante essas longas e dolorosas angústias de Joana d'Arc o que fazia o príncipe que ela havia recolocado no trono? [...] Acaso ele usou todos os seus recursos para resgatar sua libertadora dos atentados aos quais estava ameaçada? [...] envergonho-me por não ter nada a responder em defesa de Carlos VII. (SAINT-PRIX, 1817, p. 93)

De fato, a eficácia em atribuir a glória de Joana à atuação do entusiasmo parece ter sido de tal forma reconhecida por esses autores que esse tema continuaria sendo um recurso comum em muitas obras, embasando diversas opiniões, como veremos a seguir.

Sismonde de Sismondi, no 13o tomo de sua Histoire des français (1821-1844), também parte do contexto geral para explicar o surgimento e a recepção de Joana. Vinda de um meio supersticioso, influenciado pelo desejo de expulsar o estrangeiro, o "zelo popular" brilhava através dela. Algumas de suas características como a coragem, a constância, a pureza e a sabedoria unem-se à sua crença no sobrenatural e produzem uma personalidade capaz de dar à multidão o poder de fazer uma grande revolução. A partir do ambiente social, suas visões poderiam ser explicadas: como frequentemente tinha contato com os rituais na Igreja em homenagem aos santos, ela acreditava vê-los e ouvir suas vozes. Essas visóes teriam começado aos treze anos, idade em que ainda não menstruava: "[...] as enfermidades de seu sexo não a haviam atingido nessa idade. E parece que disso, ela foi sempre isenta, sendo essa uma das causas que a dispuseram aos êxtases e às ilusóes de seus órgãos.” (SISMONDI, 1831, p. 117).

O sonho contínuo em ver o Delfim coroado como Carlos VII seria o responsável por produzir os enleios nos quais ela via o que desejava: São Miguel, Santa Margarida e Santa Catarina. Esse sonho seria, segundo Sismondi, causado pelo desejo de defender sua casa, sua vila, seu país contra os borguinhões e ingleses. 
Para esse autor, o que fazia com que Joana obtivesse apoio era o fato de seu entusiasmo se estender a todos que a rodeavam. Por outro lado, devido ao espírito do tempo, a corte francesa estava disposta a acreditar que haveria uma intervenção divina a seu favor. O poder de Joana vinha de uma conjugação entre sua virtude, a "superstição universal” e a impaciência do povo em esperar por socorro.

Humilde, modesta e de boa fé em seu entusiasmo ela não duvidava da missão que suas vozes lhe deram: libertar Orléans e levar o rei a Reims; mas ela não se atribuía nenhum poder miraculoso. [...] Sua beleza, sua doçura, suas longas oraçóes, seu hábito de começar todos os seus discursos pelas palavras em nome de Deus, confirmaram os orleanenses na crença de que ela era uma santa, e que ela tinha o poder de fazer milagres em seu favor (SISMONDI, 1831, p. 123-127, grifos do autor).

No início desse trecho, verificamos que o autor se vale de temas da retórica biográfica humildade, modéstia, boa fé (DOSSE, 2009) - com o objetivo de não desqualificar o personagem devido à sua peculiaridade: a suposta capacidade de ouvir os anjos e santos. Em seguida, Sismondi articula o contexto geral às situações particulares: havia uma disposição nos espíritos para acontecimentos desse tipo. Além de transmitir entusiasmo aos moradores de Orléans e ao exército francês, devido à sua inclinação para acreditar em superstiçôes, Joana causava pavor no exército inglês que a via como bruxa e feiticeira. Mesmo antes da vitória, o sucesso do exército francês era alcançado apenas pelo terror que o nome da Donzela causava nos adversários. Ao mesmo tempo, os capitães franceses tiravam o melhor proveito possível do entusiasmo que ela trazia ao exército. Nesses dois pontos, esclarece-se o sucesso das expediçôes francesas que tinham à frente a Donzela de Orléans: os franceses venciam por estarem persuadidos da missão de Joana e os ingleses eram derrotados pelo terror supersticioso que levava ao fracasso na batalha.

A singularidade do personagem dá-se na medida em que era movida pelo entusiasmo, mas isso só poderia ser detectado pelo observador distante, posição onde Sismondi se coloca, o qual, a partir do método racional, pôde descobrir efetivamente as causas do sucesso da Donzela de Orléans.

Sismondi detecta que, após a coroação em Reims, Joana começa a perder as batalhas por ter deixado de acreditar em sua missão. Citando uma crônica do período, ele pretende comprovar que Joana não desejava continuar lutando após a coroação de Carlos VII: "Eu cumpri o que o Senhor me ordenou, que era levantar o cerco de Orléans e fazer sagrar o gentil rei; eu gostaria que ele me mandasse de volta a meu pai e minha mãe para cuidar das suas ovelhas e novilhos e fazer o que quero fazer.” (SISMONDI, 1831, p. 144).

Eis uma das questóes mais polêmicas da trajetória de Joana d'Arc ao longo do século XIX. Quando terminou a sua missão? Seria realmente em Reims, com a coroação do rei, ou ela deveria libertar toda a França? A Crônica da Donzela (citada por Sismondi) é a única fonte que testemunha o desejo de Joana em voltar para casa, encerrando as batalhas, pois a partir dos processos não se pode precisar o que Joana definia como sua missão. O fato é que esse ponto obscuro deu margem a diversas interpretações. Os católicos vão dizer que as tentativas bélicas de Joana se tornam frustradas após Reims, porque ela teria extrapolado as ordens divinas: sua missão teria terminado com a coroação de Carlos VI (KRUMEICH, 1986). Um argumento distinto, muito utilizado pelos escritores liberais, enfatiza que a causa das derrotas sofridas pela Donzela seria o fato dela receber cada vez menos dinheiro e tropas, por ter sido abandonada pelo rei e pela nobreza após 
eles terem alcançado seus objetivos. Outros autores, como Sismondi, afirmam que ela continuou lutando contra sua vontade. Essa posição, no caso de Sismondi, ajuda a reforçar seu argumento sobre o entusiasmo, uma vez que Joana, ao trair sua intuição, deixa de confiar em seus próprios atos. $\mathrm{O}$ rei e os nobres, sabendo que seu entusiasmo contagiava o exército, exigem que ela continue a reconquista da França. "[...] ela mostra a mesma coragem nos combates, a mesma constância nas dores, a mesma confiança no bom direito da França, mas não a mesma persuasão de sua missão divina, ou a mesma fé em suas inspirações.” (SISMONDI, 1831, p. 145).

A epopeia de Joana permitiu que Sismondi estabelecesse a ideia de que o entusiasmo deveria ter inflamado o chefe do governo francês, caso ele defendesse sua pátria e não seus próprios interesses, o que também lhe dá argumentos para atacar o absolutismo. Além disso, mostra que o povo deve saber que o entusiasmo pode partir dele, como se vê no exemplo de Joana d'Arc. Segundo a análise desse autor, aquele era um período em que todos interpretaram essa devoção à pátria, capaz de provocar ações gloriosas, como ação do sobrenatural. Nessa perspectiva, o período apesar de contar com uma revolução nos espíritos trazida pelas 'luzes renascentistas' (como o próprio autor afirma) ainda não oferecia explicação aos fenômenos fora do quadro do sagrado. Assim, Sismondi abre as portas para a interpretação de Michelet, vista como original, mas que, em nossa opinião, é fruto das interpretações operadas pelos autores que o antecederam.

Michelet tentou responder uma questão: o que existia de especial em Joana d'Arc, visto que em sua própria época muitas pessoas diziam ouvir vozes, autoproclamando-se enviadas de Deus? Para Michelet, a peculiaridade de Joana encontra-se em sua capacidade de criação. E é a partir dessa ideia que devemos procurar compreender a interpretação que o autor faz da história da Donzela.

Dada a impossibilidade de se passar pela história de Joana d'Arc sem levar em conta o sentimento religioso que a impulsionava, Michelet teve de confrontar a aura sobrenatural da trajetória dessa personagem, trazendo a ideia de santidade. Essa santidade, no entanto, significava um atributo gerador de poder de criação, o responsável por todo seu sucesso. Tal santidade espalhava-se entre o povo de modo que todos que a ouviam falar ficavam certos de que ela tinha parte com Deus.
A jovem menina, de sua parte, criou por assim dizer, e realizou suas próprias ideias, ela fez dela seres, ela lhes comunicava do tesouro de sua vida virginal, uma esplêndida existência. [...] A originalidade da Donzela, o que fez o seu sucesso, não foi tanto a sua bravura ou suas visões, foi o seu bom senso. Graças ao seu entusiasmo, essa moça do povo vislumbrou o problema e soube resolvê-lo. O nó que os políticos e os incrédulos não podiam desatar, ela cortou. Declarou, em nome de Deus, que Carlos VII era o herdeiro. (MICHELET, 1909, p. 27).

Como vemos, o tema do entusiasmo - aliado à santidade - também é base para Michelet construir a imagem de Joana d'Arc. Ele retoma a ideia de um entusiasmo aliado a um bom senso, já existente na obra de Sismondi, e dá-lhe novos contornos, pois, em Michelet, o entusiasmo de Joana relacionava-se ainda ao fato dela ser uma criança. "Uma criança de 12 anos, uma jovenzinha, confundindo a voz de seu coração com a voz do céu, concebe a ideia estranha, improvável, absurda, se preferirem, de executar aquilo que os homens não podem mais fazer: salvar seu país” (MICHELET, 1909, p. 27).

Para entender essa característica peculiar de Joana, devemos estar atentos à forma como Michelet via a Donzela, uma criança, para ele um ser completo, ao mesmo tempo homem e mulher. Nessa completude, o bom senso, vindo do lado masculino, unia-se ao entusiasmo, que predomina 
no seu lado feminino (BARTHES, 1991). Ao ter Joana como uma criança, percebemos que o argumento da ausência do ciclo menstrual é retomado em outros termos.

Na interpretação micheletiana, o tema do entusiasmo é crucial para se entender as ações aparentemente miraculosas. No prefácio da edição da Histoire de France, de 1869, ele faz um apanhado de sua caminhada historiográfica, e sobre sua relação com Joana d’Arc esclarece:

Admirando, amando essa personalidade sublime eu mostrei até que ponto ela é natural. O sublime não está fora do natural, a multidão é um herói. A personalidade encantadora dessa jovem camponesa era o centro e reunia tudo. Ela agiu justamente porque não possuía nenhuma arte, nenhuma taumaturgia, magia ou milagre. Seu encanto é sua humanidade. Ela não tinha asas, esse pobre anjo; é o povo, é fraca, ela somos nós, ela é todo mundo. (MICHELET, 1996, p. 23).

O tema do entusiasmo de Joana d'Arc em Michelet associa-se a um debate com importante ressonância nas discussóes políticas do século XIX. Conservadores e mesmo liberais sustentavam que as massas seriam movidas por uma espécie de insanidade. Michelet defendia a importância da insanidade heroica do povo, ao contrário de muitos intelectuais que viam nessa característica uma fraqueza perigosa, tornando necessária a presença de um guia para conter os excessos passionais da massa.

Uma característica básica da insanidade, segundo as pesquisas médicas do período, era seu caráter de contágio. As ideias não seriam meras predisposições, mas poderiam ser transmitidas de uma geração para a outra. Para a psicologia e a fisiologia da primeira metade do século XIX, as ideias saudáveis poderiam ser transmitidas entre as pessoas. Dessa forma, Michelet vê a insanidade heroica do povo como contagiosa e Joana d'A rc se torna o maior exemplo dessa associação: "Essas assim chamadas leis biológicas faziam parecer certo que o exemplo de Joana d'Arc, poderia se espalhar através da sociedade e então suceder às gerações.” (CHASE JR, 1992, p. 726).

Michelet reavalia a atuação daqueles que foram vistos como incompetentes pela sua insanidade e redefine esse conceito afirmando que as massas estavam à frente dos processos históricos. O povo continua insano, mas o desejo monomaníaco por liberdade representava as paixóes que poderiam trazer liberdade à França.

As discussões sobre o entusiasmo de Joana estavam, como se vê, em consonância com o debate científico do período. Ícones como Pinel, no contexto da Revolução Francesa, fizeram pesquisas sobre a insanidade com grande preocupação em definir questóes a respeito do contágio. Segundo os fisiologistas, as ideias obsessivas eram transmitidas em momentos críticos do ciclo biológico feminino: a menstruação e a concepção. A monomania, porém, seria contagiosa não apenas individualmente, mas poderia ser transmitida a uma civilização inteira. A mulher tem papel importante dentro dessa perspectiva, uma vez que é vista como veículo do progresso da humanidade. "O sofrimento feminino, físico e mental, era transformado em força, porque a mulher em última instância era responsável por transmitir as ideias de liberdade e sacrifício para seus filhos.” (CHASE JR, 1992, p. 727).

Michelet define quatro momentos chave de transmissão da ideia de liberdade a partir da insanidade revolucionária do povo. Esse processo teria sido deflagrado na Guerra dos Cem Anos: “Joana d'Arc começou esse processo e sua rebelião se tornou contagiosa no século XV." (CHASE JR, Idem). A transmissão geracional da ideia de fraternidade ter-se-ia dado ainda em outros 
momentos: nas guerras de religião, no período da regência durante a menoridade de Luís XV e na Revolução Francesa. A insanidade teria levado à superação da dor nesses momentos de dissolução através da fraternidade. Esse desejo vem da sabedoria da insanidade popular, sendo a verdadeira causa da Revolução de 1789.

No final do século XIV e no início do XV, a insanidade era espelhada no rei louco Carlos VI e o sentimento geral de unidade se encerrava em Joana d'Arc. O progresso da França ocorreu precisamente devido a essa confrontação dolorosa da vontade saudável de Joana versus a vontade doente de Carlos VI. A cura da França veio da combinação de um tratamento psicológico e físico iniciado por Joana d'Arc: "A Donzela sozinha, teve esse conselho e essa insanidade heroica, era a própria sabedoria.” (MICHELET, 1952, p. 249).

Michelet associa Joana definitivamente ao povo desenvolvendo o tema do entusiasmo e da insanidade em suas obras. Ela é o povo que assume, a partir do entusiasmo, seu potencial revolucionário. "Ocorre em nacionalidade o mesmo que ocorre em geologia: o calor está em baixo. Quanto mais se desce, mais ele aumenta; nas camadas inferiores é escaldante.” (MICHELET, 1988, p. 103).

$\mathrm{Na}$ medida em que fala de Joana como dotada de bom senso no entusiasmo, estabelece uma relação entre o entusiasmo e a unidade nacional. E, para ele, esse entusiasmo é o mesmo da tomada da Bastilha, quando Joana se faz presente, momento em que todas as diferenças são diluídas, enquanto na fogueira de Rouen se estabelecia a relação entre o entusiasmo e a nação: pela força do coração, o caos das províncias, algo considerado grave pelos pensadores e pelo governo francês no século XIX, ${ }^{3}$ havia se tornado uma nação.

Enquanto a união de entusiasmo e o bom senso fazem de Joana uma encarnação da ideia de unicidade, a atitude de seu rei e da nobreza em relação a ela é contrária, dando uma ideia de fragmentação: "O bom Carlos VII nada fez por ela, o bom duque Filipe entregou-a. A casa de Anjou queria a Lorena, o duque de Borgonha, o Brabante; ele queria principalmente a continuação do comércio flamengo com a Inglaterra.” (MICHELET, 1909, p. 55).

Apesar da inclusão de novos temas, como a questão da insanidade, a interpretação de Michelet sobre Joana d'Arc insere-se em uma tradição construída em torno de uma ideia difundida na historiografia joânica do período. A compreensão da imagem criada pela historiografia francesa, a partir da ideia do entusiasmo, leva-nos a reposicionar historiograficamente a biografia que Michelet escreveu sobre a Donzela. Por muito tempo, essa obra tem sido considerada um marco que teria proposto e divulgado, como nunca antes, uma nova imagem de Joana d'Arc diante da história francesa (KRUMEICH, 1993). Ao aprofundarmo-nos no tema do entusiasmo, entretanto, é possível verificar que Michelet parte de uma argumentação já consolidada por seus antecessores, que têm uma origem ainda mais remota, estando nas preocupaçôes do contexto iluminista, como veremos a seguir.

\section{A origem iluminista da discussão sobre o entusiasmo}

Ao analisar a forma como Joana d'Arc é apresentada pelos escritores do século iluminista, Jeroom Vercruysse (1972) detecta a constância do tema do entusiasmo e da persuasão interior que surgiu como uma explicação racional alternativa à crença na inspiração divina de Joana. De fato, a necessidade de posicionar-se em torno do tema das vozes de São Miguel, Santa Margarida e Santa Catarina, às quais Joana se referia como uma presença constante em sua vida desde os treze 
anos de idade, era sentida por muitos autores do século das Luzes. Nem todos se contentavam em simplesmente desconsiderar e ironizar esse tema por completo, como o fez Voltaire, e para tanto buscaram uma via inteligível que pudesse explicar o fato de Joana insistir que ouvia tais vozes, sem que isso concorresse para configurá-la como impostora ou significasse uma aceitação da intervenção sobrenatural naquele episódio da história francesa.

Uma das argumentações mais pungentes a esse respeito partiu do teólogo e doutor da Sorbonne, Nicolas Lenglet Dufresnoy, em 1753:

Acreditar que essa moça teve visões, apariçôes, revelações de santos e de santas [...] eu não acredito. [...] Mas essas aparições eu substituo por uma persuasão interior, uma meditação refletida que sacode, que anima, que agita fortemente a imaginação; e são os esforços dessa última faculdade que frequentemente nos apresentam como reais objetos que nada são além de simples imagens que nós formamos em nós mesmos. (DUFRESNOY, 1753, p. IX-X).

Sua introdução à vida de Joana esclarece-nos sobre a importância do tema no XVIII - muitos heróis são afetados pelo entusiasmo. Dufresnoy dá uma explicação sobre o heroísmo em geral, não apenas o de Joana: "O que eu chamo aqui de persuasão ou esforço da imaginação, pode-se qualificar com um título mais honorável, o de heroísmo ou entusiasmo, pois ambos nos levam à grandeza e ao sublime em açôes louváveis e virtuosas.” (DUFRESNOY, 1753, p. XV).

É possível verificar, posteriormente, como os autores vão de forma intercambiante apresentar o entusiasmo identificado ou não com a autossugestão ou por vezes admitindo que a Providência poderia atuar através de indivíduos com pré-disposição a esse entusiasmo. Muitas vezes procurou-se uma origem psicológica para o fenômeno, como fez Claude Villaret em sua Histoire de France, de 1765, o que não excluiu a continuidade do tema da Providência divina associada a esse entusiasmo como se apresenta em Dufresnoy. Em La France sous les cinque premiers Valois, de 1787, Pierre Charles Levesque explica dessa forma o sucesso das ações de Joana:

[...] jovem entusiasta que mais contribuiu para restabelecer a fortuna do Estado, passando aos espíritos as ilusões as quais assaltavam sua alma... Como ela não sofria das enfermidades periódicas de seu sexo, seu sangue se mantinha com abundância em seu cérebro e lhe causava um tipo de loucura que levou à salvação de seu Estado. ${ }^{4}$ (LEVESQUE, 1787, s. p. apud VERCRUYSSE, 1972, p. 1687).

Entre os britânicos, o tema do entusiasmo de Joana d'Arc também teve impacto. No prefácio de seu poema épico Joan of Arc, de 1795, Robert Southley esclarece:

Que ela se acreditava inspirada, poucos vão negar; que ela era de fato inspirada ninguém vai se aventurar a afirmar. [...] Entusiasmo, e não de qualquer tipo, era necessário para permitir a uma jovem donzela assumir a profissão das armas, lutar entre os demais e submeter com uma força inferior um inimigo até então tido como invencível. (SOUTHEY, 1812, p. VII-VIII)

David Hume, em The History of England, descreve e analisa brevemente a vida pública de Joana d'Arc. Para tanto, enfatiza o contexto histórico específico de seu aparecimento na Guerra dos Cem Anos, quando a cidade de Orléans estava sitiada e prestes a cair em mãos inglesas. $\mathrm{O}$ autor salienta a dificuldade dos franceses para resistir a esse sítio e destaca a grande importância do 
momento: "[...] os olhos de toda a Europa estavam voltados para essa cena, onde era razoável supor, os franceses iriam empreender sua última resistência para manter a independência de sua monarquia e os direitos de seu soberano.” (HUME, 1983, p. 394). Em seguida, sua reflexão apresenta todos os argumentos para comprovar que aquele cerco estava formidavelmente montado. As estratégias e a organização dos ingleses eram praticamente indestrutíveis. Nessa situação desesperadora, o Delfim, futuro Carlos VII, já dava a cidade como perdida e pensava em se refugiar no Languedoc ou no Delfinado.

Certamente o encadeamento dos infortúnios vividos pela França, da forma como delineado por Hume, é uma estratégia narrativa para que o leitor compreenda o significado da figura de Joana em seu entendimento. "[...] mulher de um caráter muito diferente que deu origem a mais singular das revoluçóes que pode ser encontrada na história.” (HUME, 1983, p. 397). Essa revolução teria tido um elemento propulsor no caráter peculiar da Donzela. A persuasão de Joana na sua missão causou fortes efeitos, abalando a imaginação dos combatentes ingleses. Da mesma forma, os habitantes de Orléans afetados por essa certeza acreditavam-se invencíveis sob sua influência. Essa persuasão revoluciona toda a situação anterior do cerco - os ingleses são tomados pelo pânico e os franceses são fortemente encorajados, revertendo toda a vantagem da Inglaterra, causando sua derrota e, em médio prazo, sua saída definitiva dos territórios franceses. "Os eventos em Orléans alteraram tudo entre as duas naçóes.” (HUME, 1983, p. 403).

Essa persuasão é definitivamente atrelada ao entusiasmo por Hume:

[...] ela imaginava que tinha visóes e ouvia vozes que a exortavam a restabelecer o trono da França e expulsar os invasores estrangeiros. Uma coragem incomum em seu temperamento fez com que ela se esquecesse de todos os perigos que poderia enfrentar em tal caminho e, acreditando estar destinada pelos céus a realizar esse trabalho, deixou de lado o pudor e a timidez característicos de seu sexo, sua idade e sua baixa condição social. (HUME, 1983, p. 77).

O entusiasmo teria feito com que ela ultrapassasse todas as barreiras sociais às quais estava submetida. Delineia-se a capacidade do entusiasmo de levar o herói a subverter a ordem, tema que também aparece no século XIX na historiografia francesa.

"[...] todos os sentimentos de amor e cavalaria foram unidos ao do entusiasmo para inflamar o gosto do povo pela fantasia com propensões a seu favor [de Joana]”. A fantasia em torno de Joana teria sido alimentada pelo rei e pela nobreza contra o inimigo. Depois dos acontecimentos em Orléans, todos estavam convencidos da missão divina de Joana: "Após esse sucesso nada parecia impossível para a Donzela e seus entusiásticos companheiros.” (HUME, 1983, p. 125).

Assim como Sismondi, Hume relata que Joana desejou voltar para casa depois da coroação de Charles VII, mas os nobres, interessados nos efeitos que ela causava no exército, pediram que ela continuasse as batalhas para expulsar os ingleses.

O tema do entusiasmo foi alvo das reflexões de David Hume em um escrito específico, parte de seus Ensaios morais, politicos e literários, elaborados entre 1742 e 1754. No décimo ensaio Da superstição e do entusiasmo, o autor traça uma comparação entre essas duas formas de "falsa religião", concentrando-se em analisar os diferentes efeitos que elas causam na sociedade. "Fraqueza, medo, melancolia unidos à ignorância são as verdadeiras fontes da superstição. [...] Esperança, orgulho, presunção, imaginação fértil, unidas à ignorância, são as verdadeiras fontes do entusiasmo.” (HUME, 1748, p. 1) 
Preocupado, sobretudo em mensurar a importância da atuação dessas duas tendências da mente humana ao longo do processo revolucionário inglês, Hume se detém em definir que seitas ou grupos religiosos estavam sob a influência da superstição e quais eram regidas pelo entusiasmo. Ora, para Hume, a superstição é perniciosa para a vida civil na medida em que coloca as pessoas sob o jugo do clero, já que o indivíduo se vê refém do medo causado pelas explicações sobrenaturais dos eventos e sente a necessidade de estar sob a proteção daqueles que supostamente estão em contato com o poder divino. Dessa forma, o povo não se vê como agente do seu futuro e a vida social livre é cerceada pela dominação dos sacerdotes.

No caso do entusiasmo, uma vez que nasce da presunção, gera uma autoconfiança que leva a pessoa a se ver como escolhida de Deus. Dessa forma, os grupos regidos pelo entusiasmo não veem a necessidade de intermediários no contato com o Ser Supremo, não estando, desse modo, sob o comando de um grupo de sacerdotes que poderiam definir seu destino. $\mathrm{O}$ entusiasmo, assim, levaria à liberdade civil, pois gera revolta contra a tirania do autoritarismo político.

"Como o entusiasmo vem do orgulho presunçoso e da confiança, a pessoa se julga suficientemente qualificada para se aproximar da Divindade sem nenhum mediador humano.” (HUME, 1748 , p. 2). Dessa forma, o entusiasmo atua para destruir o poder eclesiástico, ao passo que a superstição faria do homem um ser temeroso e submisso, tornando o clero tirano e perturbador da sociedade. Assim, o entusiasmo seria naturalmente acompanhado do espírito de liberdade.

Ao associar o entusiasmo à liberdade civil, David Hume, referência fundamental para os historiadores franceses escreverem sobre Joana d'Arc, abre caminho para a interpretação de Joana como defensora das liberdades políticas, imagem cristalizada nos escritores liberais do século XIX. Na verdade, o contemporâneo de Hume, Lenglet Dufresnoy, demonstrando uma conexão com os debates políticos de seu tempo, estabelece no prefácio de sua biografia de Joana d'Arc uma diferenciação entre o entusiasmo e o fanatismo, exaltando o primeiro exatamente por levar a resultados virtuosos.

As raízes dessa discussão são ainda mais profundas do que aparentam, tocando o próprio âmago das preocupações dos iluministas na Inglaterra do século XVIII. Como lembra Pocock, nesse país travou-se, entre os intelectuais, um longo debate sobre o entusiasmo vindo das reflexóes do período que eram parte do ramo do Iluminismo que se manifestou na Inglaterra: o Iluminismo Protestante.

[...] muito do que chamamos Iluminismo na Inglaterra, como Margaret Jacob efetivamente demonstrou, foi uma estratégia clerical para manter uma via media, e o panteísmo iluminista que ela chama de Iluminismo Radical foi parte do que foi atacado com o nome de spinozismo e entusiasmo. (POCOCK, 1989, p. 344, grifos do autor)

O Iluminismo Protestante continha de forma potencial em seu pensamento o ceticismo a partir do qual se buscava uma explicação histórica para o surgimento da superstição e do entusiasmo: ambos teriam sido produtos da substituição da teogonia pela religião natural. "A superstição de muitos era manipulada pela sabedoria de poucos que vieram no papel de sacerdotes” (POCOCK, 1989 , p. 348). Aqueles que se reuniam para venerar o princípio essencial de cada um aparecem no papel de entusiastas. 
A Igreja Restaurada então colocou de um lado a superstição e o sacerdócio e de outro o entusiasmo e o fanatismo; por entusiasmo, significando primeiro a falsa atribuição à inspiração pessoal ou congregacional, e em segundo lugar o erro psicopatológico de tomar as ideias ou fantasias sobre Deus pela ação ou presença de Deus na mente. (POCOCK, 1989, p. 342)

Hume introduz a possibilidade de uma visão mais positiva acerca do entusiasmo, rompendo, de certa forma, com os meios eclesiásticos e clericais nos quais essa visão fora formada. A superstição tornaria possível a ordem civil em que os seres humanos podem ser governados e o consentem. Já no entusiasmo, a mente venera a si própria. Hume desloca a superstição e o entusiasmo da relação com a História da Religião e caracteriza-os como atividades próprias da mente humana.

Quando Pocock analisa a importante discussão a respeito do entusiasmo, no século XVIII, que teve, segundo ele, papel fundamental na construção dos argumentos de Gibbon em Declínio e queda do Império Romano, ele enumera todas as contradiçôes presentes nesse debate. $\mathrm{O}$ autor lembra ainda a importância do ambiente intelectual após a Revolução Francesa para a ressignificação dessa ideia:

Tentei mostrar que o Iluminismo a partir do qual Declinio e Queda toma forma, era conservador, em seu início, no sentido de que foi direcionado não apenas contra a ortodoxia e a tradição eclesiástica, mas contra o Iluminismo e a espiritualidade populista ao mesmo tempo; e uma vez que o entusiasmo que foi denunciado como racionalista e ao mesmo tempo místico, materialista e ao mesmo tempo espiritual, a denúncia estava bem colocada para continuar, na era da revolução e redefinir entusiasmo, como Burke fez, como energia direcionada contra tudo o que dá sentido à sociedade. Os volumes conclusivos de Declínio e Queda apareceram em maio de 1788 no último momento possível antes da grande transmutação da crítica eclesiástica e filosófica ao entusiasmo, em crítica conservadora e liberal daquilo que um estudioso moderno chamou de 'fogo que ataca as mentes dos homens'. (POCOCK, 1989, p. 361)

A partir dessa linha de raciocínio, o entusiasmo popular era visto como insanidade, porém, como afirma Pocock, a interpretação acerca da influência do entusiasmo oscilava, pois, enquanto muitos viam nesse fenômeno um excesso destrutivo, outros vão interpretá-lo como fundamental na busca pela liberdade. É importante compreender o quanto essa discussão foi fundamental para que no século XIX a relação entre Joana d'Arc e o povo, e/ou o Terceiro Estado, ficasse bem sedimentada nos textos dos historiadores franceses. Nessa altura do debate, torna-se importante apresentar a posição de Voltaire que, da parte do iluminismo francês, constrói uma interpretação muito diversa da história de Joana d'Arc.

\section{Voltaire e Joana d'Arc}

La Pucelle d'Orléans, uma epopeia cômica de Voltaire, publicada em 1755, deu origem a muitos debates. De um lado, os autores católicos o acusavam de blasfêmia e, de outro, houve os que ovacionaram a obra. O poema narra fatos imaginários ocorridos com Joana d'Arc e os guerreiros franceses em várias regióes da França, Itália e até no Inferno, antes da batalha de Orléans. Voltaire criou alguns personagens bem peculiares para acompanhar Joana, como Hermafrodix que, durante o dia, era homem, mas, à noite, transformava-se em mulher e o franciscano Grisbourdon, que era feiticeiro. Joana d'Arc tinha ainda um asno voador sob seu comando. Nessa obra, ela frequentemente aparece nua e irada: 
Ele olhava de longe sua heroína

Que, nua, com a espada na mão,

O coração tomado por uma fúria divina,

Vermelha de sangue, abria caminho.

(VOLTAIRE, s/d, Canto VI, p. 101)

Além de apresentar aos leitores uma Joana d'Arc de sensualidade desmedida e provocante, ironizando a própria condição de donzela da heroína, Voltaire a coloca em situaçóes grotescas e insanas, como na estrofe a seguir, quando ela se dirige a um guerreiro francês, exigindo que ele seja sua montaria:

Responde Joana: 'Tolo, te faço graça,

Em teu sangue vil, de lodo carregado,

Não será esse ferro divino mergulhado.

Vegeta ainda, e que tua pesada massa

tenha, agora, a honra de me carregar:

Não te posso transformar em mula;

Mas não me importa tua figura:

Homem ou mula, serás minha montaria'.

(VOLTAIRE, s/d, Canto VI, p. 101.) ${ }^{6}$

$\mathrm{O}$ autor trabalhou por vinte anos nessa obra, que teve 78 edições em 45 anos. A crer no próprio Voltaire, seu objetivo ao escrever o poema era divertir seus amigos, além de fazer frente à outra obra, também intitulada La Pucelle, escrita por Chapelain, em 1625, e considerada por ele mal escrita e de gosto duvidoso. As opiniões de Voltaire a respeito de Joana d'Arc tiveram efeitos profundos e de longo alcance.

Em 1767, cinco anos após o reconhecimento oficial da obra pelo autor, ela foi condenada pela Igreja Católica Romana, passando ao Index Librorum Prohibitorum (ELEUTHÉRIO, 2012, p. 142).

Essa polêmica arrasta-se por todo o século XIX, estando bem viva na comemoração do centenário da morte do filósofo, em trinta de maio de 1878. Ele foi acusado de traidor da Pátria por grupos conservadores, devido a seus 'ataques' contra a Donzela. Nesse contexto, aqueles que comemoravam a memória de Voltaire tinham dificuldades em defendê-lo no que diz respeito à sua opinião sobre a Joana. Muitos sentiam a obrigação de se explicar publicamente. Esse foi o caso do Primeiro Ministro, León Gambetta, que disse ser possível definir-se como voltairiano e devoto de Joana d'Arc, ao mesmo tempo. Gambetta fora um dos maiores líderes anticlericais, estando à frente da causa republicana no Segundo Império francês. Dizia-se admirador e discípulo de Voltaire, mas não permitia a recitação pública do poema La Pucelle, que considerava ultrajante à memória de Joana (HEIMANN, 2005; KRUMEICH, 1993).

Um artigo publicado na Revue des deux mondes, em 1838, merece nossa atenção na reflexão sobre a recepção do posicionamento de Voltaire, acerca de Joana d'Arc, pelos historiadores franceses oitocentistas. Saint-Marc Girardin, em "La Pucelle de Chapelain et La Pucelle de Voltaire" 
(1838), traz uma análise sobre a imagem da Donzela esboçada por Voltaire em suas obras. Girardin rechaça a visão debochada do filósofo, atribuindo à sua incredulidade e ceticismo os versos "cínicos, obscenos e impiedosos" (GIRARDIN, 1838, p. 691) dedicados a Joana d'Arc no poema. Esse posicionamento não significa que Girardin se coloque como um defensor da origem divina da missão de Joana d'Arc. Ao contrário, ele pontua, em vários momentos o quão histórica e humana foi a sua trajetória, contextualizando e localizando politicamente suas ações. "Nada na história que seja acidental, nada que seja acaso ou prodígio.” (GIRARDIN, 1838, p. 693). Ele ainda ataca, com propriedade, argumentos e fontes, erros históricos no verbete La Pucelle, de Voltaire, publicado no Dictionnaire Philosophique. Segundo ele, para descaracterizar a importância das açôes de Joana d'Arc, Voltaire vale-se de um engodo criado após a morte da Donzela, por seus algozes, conforme o qual, haveria um monge, de nome Richard, que teria guiado três mulheres ditas inspiradas, dentre as quais a própria Joana d'Arc. De acordo com essa invenção, citada por Voltaire a partir da predicação de um inquisidor dominicano, o tal Richard seria um trapaceiro, que enganava e direcionava as ações e supostas visões das jovens. Para Girardin, nesse fato, pode-se ter a dimensão do ponto a que Voltaire chegou para desqualificar Joana d'Arc e sua trajetória: “[...] estar em acordo com um dominicano e inquisidor da fé, para caluniar uma santa e nobre moça, culpada do crime de ter libertado a França do jugo estrangeiro.” (GIRARDIN, 1838, p. 694).

Girardin também acusa Voltaire de tomar partido dos ingleses. Se há beleza ou bravura em La Pucelle, ela vem do exército inimigo, jamais dos franceses ou de Joana. O autor atribui essa postura ao exílio de Voltaire na Inglaterra "[...] ele foi recebido e festejado em Londres. Foi lá que ele fez sua educação irreligiosa.” (GIRARDIN, 1838, p. 698). Sua inspiração parece ter sido do inferno, não do medieval, mas um inferno cínico e vergonhoso. "Esse poema é uma caricatura da humanidade, um longo escárnio do homem.” (GIRARDIN, 1838, p. 703).

A grande importância desse artigo reside no fato dele ser praticamente a única crítica aberta e contundente de um escritor, de posicionamento liberal, contra a principal obra de Voltaire a respeito de Joana d'Arc. Desde o período da Restauração Monárquica, foram comuns as acusações a Voltaire, por parte dos monarquistas católicos, que associavam o período revolucionário aos malefícios causados pelos iluministas, frequentemente utilizando Voltaire e seu desprezo pela Donzela para demonstrar a grande catástrofe moral preconizada pelo processo revolucionário, seus governos e sua legislação.

Também no verbete La Pucelle, no Dictionnaire Philosophique, de 1764, apesar de apresentar uma linguagem mais formal, adequando-se ao objetivo da obra, Voltaire desacredita Joana d'Arc como heroína francesa. Nesse texto, ele coloca em xeque as previsões da Donzela, debocha dos supostos milagres em sua trajetória e apresenta-a como uma camponesa ingênua, manipulada por aqueles que se valiam das crendices e do fanatismo para encorajar seus soldados. "É uma infeliz simplória, que tinha tido coragem o bastante para render enormes serviços ao rei e à pátria, foi condenada à fogueira por quarenta e quatro padres franceses que a imolaram à facção da Inglaterra" (VOLTAIRE, 1764, p. 5).

E, apesar de criticar duramente os juízes de Joana d'Arc e de caracterizar como barbárie sua morte na fogueira, Voltaire tem Joana tão somente como uma rude camponesa, iludida pela crendice e morta pelas armações políticas do período.

Assim sendo, toda a movimentação política, militar e religiosa provocada pela vida pública de Joana d'Arc é interpretada de maneira bem diversa por Voltaire. Não seria jamais vista como 
uma mobilização com potencial catalizador para a luta em busca da liberdade humana, como o foi para Hume, para quem a autossugestão própria do entusiasmo leva a resultados concretos.

O destino de Joana, com sua morte na fogueira, seria uma lição contra o fanatismo, segundo Voltaire. Mas, toda a superstição em torno dela não permite que isso seja visto, pois os franceses daquele período nada aprenderam com o final trágico da ignorante camponesa. Para Hume, ao contrário, o caso de Joana seria um exemplo de como o entusiasmo - e não o fanatismo - pode levar a resultados positivos, como a liberdade civil.

Voltaire não buscou destruir a aura de sacralidade em torno de Joana, colocando-a como uma heroína laica, defensora de valores iluministas, ideia a ser construída pelo século XIX. Ele buscou desmistificá-la, atribuindo-lhe características, comportamentos e aparência grotescos. É por isso que se o século XIX não tivesse seguido a via do entusiasmo, da autossugestão potencialmente geradora de resultados positivos, teria sido impossível que ela se mantivesse como heroína e, sobretudo, nacional e republicana.

Sob nosso ponto de vista, as obras oitocentistas analisadas na primeira parte do artigo são parte de uma longa resposta dada pela intelectualidade francesa à posição de Voltaire a respeito de Joana d'Arc. A nosso ver, o grande impacto de seu posicionamento levou à necessidade de uma definição, pelos próprios escritores franceses, da verdadeira importância de Joana d'Arc para sua história. Ao elegerem o tema do entusiasmo para a explicação das ações de Joana, optam pela interpretação humeana que o relaciona à liberdade civil. A escolha da interpretação de um também filósofo, David Hume, tão engajado quanto Voltaire nas temáticas mais profundas e significativas que apontassem o caminho para a libertação do espírito humano, marca a historiografia joânica a partir do século XVIII para que a Donzela não fosse descartada como heroína. Esse trabalho da construção da imagem de Joana como heroína nacional laica foi sedimentado pela historiografia nacionalista do século XIX, tendo como expoentes muitos dos autores já mencionados.

A opção pela interpretação humeana da ideia de entusiasmo reflete-se, com clareza, na historiografia joânica da primeira metade do século XIX, tornando-se um ponto fundamental na construção da noção de povo e nação para os franceses. A forma como vários desses autores apresenta a história de Joana d'Arc segue o mesmo encadeamento narrativo de David Hume. Além disso, a atribuição da inspiração de Joana vir de um sentimento geral da sociedade contra a situação de guerra permanente é um argumento de Hume, utilizado por Sismondi para também explicar a mobilização do entusiasmo de Joana em prol do Reino Francês. Além dos liberais, a influência da intepretação humeana está clara nos escritores monarquistas da Restauração, pois, além de trazerem o tema do entusiasmo como fundamental, a History of England consta, não apenas na bibliografia dessas obras, como também é citada e referida em notas explicativas; Berriat Saint-Prix, por exemplo, cita Hume 87 vezes!

A posição de Girardin aponta, obviamente, para outro momento, quando pensa-se a trajetória de Joana d'Arc em consonância com a História Nacional Francesa, algo distante dos propósitos de Voltaire em relação à Donzela. O caminho proposto por Hume era muito mais condizente com os objetivos oitocentistas da criação de heróis nacionais que pudessem ser relacionados à grandiosidade do povo, o qual se desejava descrever e criar. 


\section{Hume, Voltaire e a historiografia francesa}

A reivindicação de uma relação direta com o divino e o sucesso nas ações que daí se origina, denominado de entusiasmo, tem uma interpretação muito diferente dentro das discussóes do Iluminismo inglês. No caso de Joana, em particular, a influência de Hume é definitiva, pois ele oferece uma interpretação que permitia associar o fenômeno a um tema caro ao período: a liberdade civil.

A nova visão sobre Joana d'Arc no século XIX, nesse aspecto, é tributária do Iluminismo Protestante e de sua influência entre os franceses. Não se optou pela interpretação voltairiana, que, uma vez adotada, descartaria Joana d'Arc como uma heroína. Bem ao contrário, para Voltaire, ela era apenas uma representante do fanatismo e ignorância em que viviam o povo francês do século XV. Prova disso foi sua ingenuidade ao lutar por um rei mesquinho e ingrato, ingenuidade que lhe custou a própria vida. Dessa forma, os sentimentos que Voltaire demonstrava por Joana iam da compaixão ao desprezo, os mesmos que nutria pela Idade Média, período em que o obscurantismo teria impedido as pessoas de enxergarem a verdade. Muito mais diversificada, como vimos, foi a via interpretativa para o mesmo fenômeno entre os intelectuais ingleses desse período.

Segundo Contamine (1987), a historiografia joânica, entre os séculos XVI e XVIII, evoluiu ao sabor das circunstâncias políticas, sendo dominada pela interpretação providencialista. Nossa hipótese é de que esse período não pode ser visto em bloco. No que se refere ao século XVIII, deve ser levada em conta uma continuidade interpretativa que é salientada na relação entre os textos de Lenglet Dufresnoy e David Hume com uma tradição sobre o tema do entusiasmo que possui ecos no século XIX.

É curioso o fato de uma importante obra dedicada à Joana d'Arc, o dicionário organizado por dois importantes medievalistas e grandes referências quando se trata dessa personagem, Philippe Contamine e Olivier Bouzy (2012), não possuir a entrada entusiasmo, conceito que não é discutido nem mesmo na primeira parte da obra que possui um consistente debate historiográfico. Nem ao menos no verbete psiquiatria o problema das vozes é associado ao entusiasmo. A referência vai direto ao século XIX, trazendo apenas a informação de que, em 1845, o médico Louis-Florentin Calmeil escreveu um tratado chamado De la folie, no qual dedicou um capítulo à teomania de Joana d'Arc. Mas, como afirmamos anteriormente, trata-se de uma discussão anterior, mais ampla, tocando o próprio princípio iluminista do devotamento à razão, a qual é importante para compreender como o período medieval passou a ser interpretado pelos oitocentistas.

Além disso, nesse mesmo dicionário, o verbete Voltaire afirma que sua obra a respeito de Joana d'Arc não teve impacto importante. Segundo Olivier Bouzy, o poema de Voltaire é uma crítica a Carlos VII e, por meio dele, a Luís XIV e sua corte. "Apesar de suas 78 edições em 45 anos a influência do poema de Voltaire não deve ser superestimada.” (BOUZY, 2012, p. 1043). Ainda que o autor considere que Voltaire tenha sido mais influenciado pela literatura da época do que servido de inspiração para outros autores, o impacto do posicionamento de Voltaire deve ser levado em conta. Acreditamos que, ao negligenciarem a recepção das opiniões de Voltaire sobre Joana d'Arc e não atentarem para a definitiva influência de David Hume na historiografia francesa, esses especialistas se afastam de um dos principais elementos constitutivos da imagem de Joana d'Arc no século XIX, o entusiasmo. Ao associar o entusiasmo à liberdade civil David Hume, referência fundamental para os historiadores franceses escreverem sobre Joana d'Arc, abre caminho para a 
interpretação de Joana como defensora das liberdades políticas, imagem cristalizada nos escritores liberais do século XIX.

Para a maioria dos autores da primeira metade do século XIX, o que fez com que Joana tivesse sucesso foi, sem dúvida, o entusiasmo. Porém, eles vão encontrar uma explicação para a aceitação de Joana julgando seu contexto histórico obscuro e propenso à interpretação de qualquer fenômeno como sobrenatural, exatamente como David Hume fez. Os contemporâneos de Joana aceitavam-na, mas não sabiam o que, de fato, estava acontecendo, devido ao obscurantismo da época. Sismondi, como vimos, atribui ao clima de superstição generalizada a visão deturpada de que Joana d'Arc era encarregada de uma missão divina. Além disso, esse contexto supersticioso explicaria vários outros acontecimentos como o julgamento injusto, bem como o abandono de Joana pelo rei.

L’Averdy, no momento em que defende Carlos VII das acusaçôes de ter abandonado Joana d'Arc, encontra nesse argumento a explicação: "Oh! Como calcular os efeitos funestos que poderiam resultar contra ele nesse tempo de profunda ignorância, em que a França e a Inglaterra só poderiam ser habitadas por homens do século XV?” (L'AVERDY, 1790, p. 170).

Já Lebrun des Charmettes, atribui o julgamento de Joana à barbárie do século XV: "A história desse tempo de ignorância e de barbárie oferece numerosos exemplos do esquecimento da benevolência na conduta dessa multidão de eclesiásticos.” (CHARMETTES, 1831, p. 107).

Também em Michelet, o contexto em que Joana viveu aparece como os últimos suspiros de uma agonizante Idade Média na qual já se podiam ver rastros de um sentimento nacional. "Na fogueira de Rouen terminava a Idade Média e começavam os tempos modernos.” (MICHELET, 1996, p. 300). É por isso que para Michelet a originalidade de Joana não estava em suas visões: "Quem não as tinha na Idade Média?” (MICHELET, 1909, p. 13).

Michelet (1909) e Quicherat (1850) afirmaram que Joana d'Arc foi a última santa da Idade Média e a primeira mártir de uma modernidade que rompe com tais misticismos e superstiçóes. Aqueles que não entenderam Joana pensavam que faziam isso por motivos religiosos ou supersticiosos, mas para Michelet tratava-se de uma resistência contra a modernidade. $\mathrm{O}$ fato de Paris fechar as portas para a Donzela significava que eles estavam contra o progresso, ou seja, contra a nação, contra sua unidade. Também Girardin (1838), quando fala do entusiasmo, patriótico e político que corria a França de um canto a outro, ele diz que esse entusiasmo inspirou Joana d'Arc. "A causa da independência nacional tinha se tornado uma religião. Ela tinha seus santos, seus mártires e seus perseguidores” (GIRARDIN, 1838, p. 694).

O debate sobre o entusiasmo racionaliza a interpretação e ao mesmo tempo permite que Joana seja ligada à questão nacional sem que o sobrenatural tenha peso decisivo. A utilização dessa ideia faz com que os autores se vejam no uso de sua racionalidade e objetividade e, na medida em que associam a crença das pessoas na ação de Joana como fruto da superstição da época, cria uma ideia de infância da nação francesa localizada no período medieval, em que não se tinha consciência do nacional, muito embora já agissem intuitivamente em defesa dessa ideia. Como vimos, a discussão a respeito do entusiasmo não surgiu no século XIX, sendo importante para as interpretaçôes racionalistas do período iluminista. Mas, foi uma ideia fundamental para que o século XIX não descartasse Joana d'Arc como heroína nacional em um período no qual a história precisava ressignificar o passado e estabelecer referências identitárias com a criação de heróis.

A tradição iluminista serviu de referência teórica para a construção da imagem de Joana, contribuindo para definir o caráter laico desejado pelos oitocentistas. Nesse sentido, a universalidade 
preconizada pelos ilustrados encontrou espaço entre os historiadores que, influenciados pelo Romantismo, enfatizaram a importância das ações individuais nos processos históricos. A epopeia de Joana servia ainda às discussóes sobre o papel revolucionário do povo que estavam submetidas à mesma dupla influência, iluminista e à romântica.

Em nossa opinião, a interpretação de David Hume direcionou as discussões oitocentistas. Ao relacionar esse tipo de "temperamento arrojado" à liberdade civil, ele lança as bases para uma interpretação que postula a Guerra dos Cem Anos como momento primordial da luta pela liberdade na França, como afirmam Sismondi e Michelet.

Joana é heroína não por sua santidade, mas por reconhecer o legítimo governante e lutar por ele. Nos autores denominados "liberais", como é o caso de Sismondi e Michelet, a ideia central vem da mesma origem dos autores da Restauração: uma Joana dessacralizada, movida pelo entusiasmo, uma heroína contextualizada e, sobretudo, explicável e apreensível do ponto de vista nacional.

No século XVIII, o entusiasmo foi uma alternativa à tese do sobrenatural e pôde dar um ar racional à história de Joana d'Arc. Na verdade, contribuiu para minimizar ou mesmo anular as interpretaçóes religiosas a respeito da Donzela. $\mathrm{O}$ apelo a uma interpretação racional do entusiasmo relaciona-se a uma tentativa de minimizar a importância da relação com o sobrenatural para os homens do XVIII o que, conforme análise de Claire Oliveira, seria o artifício da Razão como forma de controle social:

Michael Heyd mostra que a escolha de uma explicação natural, médica (pela melancolia), do entusiasmo, ao invés das explicaçóes sobrenaturais e demonológicas, obedece a uma vontade de reduzir ao silêncio os oponentes religiosos. $\mathrm{O}$ racionalismo anunciado por aqueles que criticam o entusiasmo mascara a sua vontade de controle das formas de dissidência religiosa (HEYD, 1995, p. 1). Ser sóbrio e racional, para os defensores da ortodoxia anglicana, é conformar-se à doutrina estabelecida, é recusar qualquer divergência daquilo que é definido como norma em matéria de comportamento religioso. $\mathrm{O}$ apelo à razão, nos primórdios do Iluminismo inglês, é muito mais ambivalente do que parece à primeira vista e pode também ser compreendido como a manifestação de uma restrição social, pois “[...] a razão - mesmo após a época liberal - sempre simpatizou com o controle social” (ADORNO; HORKHEIMER, 1974, p. 30) que se exerce sobre os espíritos e também sobre os corpos. (OLIVEIRA, 2006, p. 84)

Em nossa opinião a "racionalização" ou "laicização" da história de Joana d'Arc através da ressignificação do entusiasmo, a partir da qual ela foi associada definitivamente ao "povo francês", é o aspecto mais fundamental debatido pela historiografia joânica na primeira metade do século XIX. Ele explica em grande parte o sucesso e a popularização definitiva de Joana d'Arc nas décadas seguintes. A partir de nossas pesquisas, porém pudemos perceber que se trata de uma discussão muito anterior, mais ampla, tocando o próprio princípio iluminista do devotamento à razão, a qual é importante para compreender como o período medieval passou a ser interpretado pelos historiadores do século XIX.

Se no século XVIII há uma preocupação em explicar apenas racionalmente a atitude singular de Joana d'Arc, o século XIX parte dessa explicação para dar um novo significado às suas açóes, que passam a ser relacionadas à defesa da nação, ao heroísmo popular e à sua capacidade de definir os rumos da história das sociedades. Tal reflexão leva-nos a reforçar o cuidado em relação a análises que tendem a interpretar o século XIX como um todo, e sua historiografia em particular, como um momento de total originalidade e ruptura. $\mathrm{O}$ debate sobre o tema do entusiasmo dá-nos a 
oportunidade de perscrutar a trajetória de uma tradição discursiva que nos permite reposicionar a historiografia joânica da primeira metade do século XIX. Não há, nesse sentido, a clássica oposição entre monarquistas e liberais. Tampouco Michelet desponta como um arauto de uma interpretação completamente original sobre Joana d'Arc. E, acima de tudo, o debate em torno do entusiasmo de Joana configura-se como o principal elemento na elaboração de uma narrativa que promove a Donzela de Orléans à condição de heroína laica, republicana e representante do Terceiro Estado. Isso foi possível graças à grande influência de David Hume, em resposta indireta a Voltaire.

\section{Referências}

AMALVI, Christian. Le goût du Moyen Âge. Paris: Boutique de L'Histoire, 2002.

AMARAL, Flávia A. História e ressignificação: Joana d'Arc e a historiografia francesa da primeira metade do século XIX. Tese. (Doutorado em História Social). Universidade de São Paulo, São Paulo, 2012.

BARTHES, Roland. Michelet. São Paulo: Companhia das Letras, 1991.

BEAUNE, Colette. Joana d'Arc. Tradução de Marcos Flamínio Peres. São Paulo: Globo, 2006.

BOUZY, Olivier. Manuscrits inutiles et auteurs inconnus: la transmission du souvenir de Jeanne d'Arc du XVe au XVIIle siècle. Bulletin des Amis du Centre Jeanne d'Arc, n. 26, 2002. p. 23-52.

BOUZY, Olivier; CONTAMINE, Philippe; HÉLARY, Xavier. Jeanne d'Arc: Histoire et dictionnaire. Paris: Bouquins, 2012.

CHASE JR., Richard. Jules Michelet and the Nineteenth-Century Concept of Insanity: A Romantic's Reinterpretation. In: French Historical Studies, v. 17, n. 3, p. 725-746, 1992.

CONTAMINE, Phillipe. L'action et la persone de Jeanne d'Arc. Remarque sur l'attitude des princes français à son egard. In: Bulletin de La Societé Historique de Compiégne. v. 28, 1982. p. 63-80.

CONTAMINE, Phillipe. Naissance d'historiogaphie. Le souvenir de Jeanne d'Arc en France et hors de France depuis le 'procés de son innocence' jusqu'au début du XVle siècle. In: Francia. v. 15, 1987.

CROSSLEY, Ceri. French historians and romanticism: Thierry, Guizot, the Saint Simonians, Quinet, Michelet. London; New York: Routledge, 1993.

DOSSE, François. O desafio biográfico - escrever uma vida. São Paulo: Edusp, 2009.

DUFRESNOY, Nicolas L. Histoire de Jeanne d'Arc, dite la Pucelle d'Orleans, vierge, héroïne et martyre d'état: suscitée par la providence pour rétablir la monarchie française. Paris: Coutellier, p. 1753-1754, 1753.

ELEUTHÉRIO, Mayquel F. O Filósofo e a Donzela: a corrosão do mito de Joana d'Arc por Voltaire em La Pucelle d'Orléans. Aedos. Porto Alegre. Universidade Federal do Rio Grande do Sul, n. 10 v. 4, jan./jul. 2012.

GARCIA, Patrick et al. Les courants historiques en France. XIXe-XXe siècle. Paris: Armand Colin, 2005.

GIRARDIN, Saint-Marc. La Pucelle de Chapelain et La Pucelle de Voltaire. In: Revue des deux mondes, v. 15. Paris, 1838.

HEIMANN, Nora M. Joan of Arc in French Art and Culture (1700-855): From Satire to Sanctity. Routledge, 2005.

HUME, David. Essays Moral, Political, and Literary (1742-1754). Essay X: of superstition and enthusiasm. Disponível em: http://www.english.upenn.edu/ mgamer/Etexts/hume.superstition.html. Acesso em:12 mar. 2017.

HUME, David. The History of England from the Invasion of Julius Caesar to the Revolution in 1688. Indianapolis: Liberty Fund, 1983. v. 2. Chapter: XX: HENRY VI. Disponível em: http://oll.libertyfund.org/title/789/67294. Acesso em: 13 out. 2017.

KRUMEICH, Gerd. Controverses historiographiques autour de la mission de Jeanne d'Arc au XIXe siècle. Bulletin des Amis du Centre Jeanne d'Arc, n. 10, 1986. p. 33-40.

KRUMEICH, Gerd. Jeanne d'Arc à travers l'histoire. Paris: Albin Michel, 1993. 
KRUMEICH, Gerd. Jeanne d'Arc dans les encyclopedies françaises du XIXe siécle. Bulletin de l'Association des amis du centre Jeanne d'Arc. Paris, n. 5, 1982.

KRUMEICH, Gerd. Jeanne d'Arc dans l'Histoires de France ao XIXe siécle. Paris: Conference dactylographiée. Institut philosophique allemand, 1982.

L'AVERDY, C. Notices et extraits des manuscrits de la Bibliothèque du roi, lus au comité établi par sa Majesté dans l'Académie royale des Inscriptions et Belles Lettres. 1790. Disponível em: https://gallica.bnf.fr/ark:/12148/ cb32824817b/date. Acesso em: 6 jan. 2020.

LEBRUN DES CHARMETTES. Epitres politiques sur nos extravagances. Paris, 1831. Disponível em: https:// gallica.bnf.fr/ark:/12148/bpt6k28483x. Acesso em: 15 jan. 2020.

MARTIN, Philippe (org.). Jeanne d'Arc: les métamorphoses d'une héroïne. Nancy: Place Stanislas, 2009.

MAURICE, Jean; COUTY, Daniel. Images de Jeanne d'Arc. Actes du colloque de Rouen. Paris: Presses Universitaires de France, 2000.

MICHAUD-FRÉJAVILLE, Françoise. Personne, personnage: Jeanne d’Arc en France au XVIle siècle. In: Jeanne d'Arc en garde à vue, sous la direction de Dominique Goy-Blanquet. Bruxelles: Le Cri Edition, 1999. p. 55-77.

MICHELET, Jules. Histoire de France. Anot. de Charles Marc des Granges. Paris: Hatier, 1946.

MICHELET, Jules. Histoire de la Révolution française. Paris: Gallimard, 1952.

MICHELET, Jules. Jeanne d'Arc. Avec une introd. et un répertoire explicatif des notes de Michelet par Émile Bourgeois. Paris: Librairie Hachette, 1909.

MICHELET, Jules. Oeuvres Complétes - 1832-1839. Paris: Flammarion, 1996.

MICHELET, Jules. O Povo. São Paulo: Martins Fontes, 1988.

MICHELET, Jules. Sur l'histoire des Français de Sismondi. In: MICHELET, Jules. Ouevres Complétes. Paris: Flammarion, 1996.

NETTEMENT, Alfred. La mission de Jeanne d'Arc. In: Revue des questions historiques. Oc., 1866. p. 526-561.

OLIVEIRA, Claire C. Ser sóbrio e racional: os usos ambíguos da razão na literatura dietética dos primórdios das luzes inglesas. In: Scientiae Studia. v. 4 n. 1. São Paulo, jan./mar. 2006. Disponível em: http://www.scielo. br/scielo.php?pid=S167831662006000100004\&script=sci_arttex. Acesso em: 23 out. 2017.

POCOCK, John Greville Agard. Edward Gibbon in History: aspects of the Text in The History of the Decline and Fall of the Roman Empire. The Tanner Lectures on Human Values. New Have: Delivered at Yale University. March 1-3, 1989.

QUICHERAT, Jules. Aperçus nouveaux sur l'histoire de Jeanne d'Arc. Paris: Jules Renouard, 1850.

QUICHERAT, Jules. Procès de condamnation et de réhabilitation de Jeanne d'Arc, dite la Pucelle, publiés pour la première fois d'après les manucrits de la Bibliothèque nationale, suivis de tous les documents historiques qu'on a pu réunir, et accompagnés de notes et d'éclaircissements. vol. 5. Paris: Jules Renouard, 1841-1849.

RUDLER, Gustave. Michelet: historien de Jeanne d'Arc. Paris: PUF, 1925.

SEGAL, Lester A. Nicolas Lenglet Du Fresnoy: Tradition and change in French Historiographical thought on the early Eighteenth Century. In: Studies on Voltaire and the eighteenth Century. v. 98, 1972. p. 69-117.

SISMONDI, Sismondi. Histoire des Français. v. 13. Paris, 1831.

SOUTHEY, Robert. Joan of Arc. An epic poem. Londres: Longman, 1812.

VERCRUYSSE, Jeroom. Jeanne d'Arc au Siècle des Lumières. In: Studies on Voltaire and the Eighteenth Century. v. 90,1972. p. 1659-1729.

VIALLANEIX, Paul. La Jeanne d'Arc de Jules Michelet, légende romantique. In: Travaux de linguistique et de literature, t. XVII, n. 2, Études litteraires. Strasbourg: Université de Strasbourg, 1979. p. 05-114.

VOLTAIRE. Dictionnaire philosophique. Paris: Garnier, s/d.

VOLTAIRE. La Pucelle d'Orléans. Paris: Verda, s/d.

WARNER, Marina. Joan of Arc. The image of female heroism. New York: Alfred A. Knopf, 1981. 


\section{Notas}

${ }^{1}$ A própria Joana, em sua vida pública, adota para si a denominação La Pucelle, forma que aparecerá em inúmeros documentos desde então. Nas fontes contemporâneas e nos processos, seu nome aparece simplesmente como "Jehanne", "Jehanne, la Pucelle" ou “Jehanne Darc". O uso do apóstrofo em seu nome como ficou consagrado - "d'Arc" - é considerado anacrônico por vários autores, pois, como observou Marina Warner, esse caractere só aparece nos nomes das famílias francesas a partir do Renascimento. No entanto, optamos por manter em nosso texto a forma mais adotada em português, Joana d'Arc, usando de forma intercambiante o epíteto “Donzela”. (WARNER, 1981).

${ }^{2}$ Todas as fontes analisadas neste artigo foram trabalhadas em sua língua original. As citações em português são traduções livres, de nossa autoria. (L'AVERDY, 1790, p. 57).

${ }^{3}$ Ao longo do século XIX, coloca-se em prática um projeto de construção da nacionalidade francesa. A diversidade linguística e as diferenças culturais entre as províncias eram consideradas as principais barreiras à construção da nação. Em Michelet, Joana d'Arc é a precursora desse movimento cujo objetivo era apagar as diferenças regionais e mobilizar o potencial revolucionário do povo. Essa discussão pode ser conferida no seguinte trabalho: AMARAL, F. História e ressignificação: Joana d'Arc e a historiografia francesa da primeira metade do século XIX. Tese. USP, 2012.

${ }^{4}$ Esse testemunho revela que mais uma questão debatida no século XIX - a ausência do ciclo menstrual - foi suscitada no século XVIII e relacionada à questão do entusiasmo. Em Lebrun des Charmettes, esse tema é também retomado para explicar o sucesso de Joana em seus empreendimentos. Também Michelet, ao ver Joana como uma criança, busca nessa mesma argumentação do século XVIII a explicação sobre o poder de criação de Joana d'Arc que faz dela a encarnação da França.

${ }^{5}$ Existem ainda outros autores como William Guthrie que, em A general history of England, desenvolve esse tema vendo em Joana "[...] nada além de entusiasmo, que é uma sincera, calorosa e desinteressada operação da mente." (GUTHRIE, 1747, s. p. apud VERCRUYSSE, 1972, p. 1688).

${ }^{6}$ Tradução de Mayquel Ferreira Eleuthério, O Filósofo e a Donzela: a corrosão do mito de Joana d’Arc por Voltaire em La Pucelle d'Orléans.

Recebido em: 22/10/2019

Aprovado em: 20/03/2020 